\title{
BUILDING IPC4D TO PROMOTE ACCESS TO ESSENTIAL MEDICINES
}

\author{
Peter K. Yu ${ }^{*}$
}

\section{INTRODUCTION}

On December 6, 2005, shortly before the World Trade Organization (WTO) Ministerial Conference in Hong Kong, WTO member states agreed to accept a protocol of amendment to the Agreement on Trade-Related Aspects of Intellectual Property Rights (TRIPs Agreement). This amendment sought to provide a permanent solution to implement paragraph 6 of the Doha Declaration on the TRIPS Agreement and Public Health (Doha Declaration). If ratified by two-thirds of the WTO membership by December 2009, the proposed Article 31bis of the TRIPs Agreement will allow countries with insufficient or no manufacturing capacity to import generic versions of on-patent pharmaceuticals. ${ }^{1}$

To facilitate the supply of essential medicines to countries with insufficient or no manufacturing capacity, the proposed amendment creates a special arrangement not only for the affected countries, but also for those belonging to a regional trade agreement. Such an arrangement allows less developed countries - including both developing and least developed countries ${ }^{2}$ - to aggregate their markets to generate the purchasing power needed to make the development of an indigenous pharmaceutical industry attractive ( $\mathrm{Yu}$ $2007 \mathrm{~b}, 848$ ). The provision also paves the way for the development of regional supply centres, procurement systems, and patent pools and institutions, while facilitating technical cooperation within the region (Abbott and Reichman 2003, 973-77; Musungu, Villanueva, and Blasetti 2004, xv-xvi).

Unfortunately, because Article 31bis specifically requires that least developed countries make up at least half of the membership of any beneficiary regional trade agreement, the provision would benefit only a limited number of less developed countries, predominantly those in Africa. Even worse, the interpretation of the provision remains contested within the WTO. While the European Communities "insisted that the [provision] should be limited to what is effectively sub-Saharan Africa," less developed countries in Asia, the Caribbean, and South America embrace a much broader interpretation of Article 31bis (Abbott and Reichman 2003, 945).

In light of the limited benefits of the proposed amendment to the TRIPs Agreement, this chapter explores how greater collaboration among less developed countries can promote access to essential medicines in the less developed world. The chapter begins by explaining how building intellectual property coalitions for

* Copyright (C 2008 Peter K. Yu. This chapter has been abridged and adapted from Yu, Peter K. 2008. "Access to Medicines, BRICS Alliances, and Collective Action." American Journal of Law and Medicine 34: 345-94. 
development (IPC4D) can help less developed countries strengthen their collective bargaining position, influence negotiation outcomes, and promote effective and democratic decision making in the international intellectual property regime. It then discusses four coordination strategies that can be used to develop these coalitions. The chapter concludes with a discussion of the various challenges confronting the creation and maintenance of these coalitions.

\section{IP Coalitions for Development}

IPC4D is a concept that can take many different forms - blocs, alliances, regional integration, or other cooperative arrangement. The resulting coalitions have several attractive features. By bringing countries together, the coalitions can achieve leverage that does not exist for each less developed country on its own. If used strategically, they will enable less developed countries to shape a pro-development agenda, articulate more coherent positions, or even establish a united negotiating front. The coalitions will also help less developed countries establish a more powerful voice in the international debates on public health, intellectual property, and international trade. In doing so, countries will be able to develop treaties and policies that promote access to essential medicines in the less developed world.

Moreover, from the standpoint of international relations, the creation of IPC4D will help many less developed countries combat the external pressure that each country will face on a one-to-one basis from the European Communities, the United States, or other powerful trading partners (Bird and Cahoy 2008, 317). With the appropriate arrangements, these coalitions may even facilitate the transfer of technology from the haves to the have-nots, targeting a major weakness of the current international intellectual property regime (Yu 2008a, 368-69).

If regional coalitions are set up — such as through regional economic integration; the institution of regional organizations, mutual recognition systems, or procurement systems; the facilitation of regional cooperation in research and development; or the creation of regional competition enforcement mechanisms - there may be additional benefits. As Sisule Musungu, Susan Villanueva, and Roxana Blasetti (2004, xiv) have noted in a South Centre study:

A regional approach to the use of TRIPS flexibilities will enable similarly situated countries to address their constraints jointly by drawing on each others' expertise and experience and by pooling and sharing resources and information. This approach has several advantages. First, it creates better policy conditions for addressing the challenges of implementing TRIPS flexibilities, which can be daunting for each individual country. Second, a common approach to improve access to essential medicines will enhance the efforts by developing countries to pursue common negotiating positions at the WTO and in other multilateral negotiations such as those on a substantive patent law at the World Intellectual Property Organization (WIPO). In addition, a regional approach coincides with the objective of enhancing SouthSouth cooperation on health and development. 


\section{BUILDING IPC4D TO PROMOTE ACCESS TO ESSENTIAL MEDICINES}

Consequently, if strategically utilized, regional South-South frameworks will significantly help developing countries devise ways by which national constraints in the use of TRIPS flexibilities can be overcome.

Likewise, two political scientists remind us that "[s]hared historical experiences among states of a particular region develop over time ... and the cultural affinities which facilitate commerce are more likely with neighbouring peoples than with those from afar" (Coleman and Underhill 1998, 1). It is, therefore, no surprise that Amrita Narlikar (2003, 155) finds "coalitions that utilize regionalism as a springboard for bargaining [to] be ... "natural coalitions.",

Indeed, regional coalitions can serve as a fairly effective strategy to promote access to essential medicines in the less developed world. As stated further in the South Centre study (Musungu, Villanueva, and Blasetti 2004, 35-36):

[A] regional approach can provide incentives for establishing or developing regional pharmaceutical production and help expand research capabilities. In addition, higher effective demand for the same medicines due to climatic conditions and other geographical reasons, as well as cultural aspects, will result in lower consumer drug prices due to increased economies of scale in procurement and distribution. Other important benefits include: the costs associated with adapting medicines to the region may be offset/lowered due to increased economies of scale; stronger local technological capacities/domestic innovation resulting from the pooling of adequate resources including financing, and human capital and physical capital will be stimulated. Finally, a regional approach can also help to improve cross-border disease control.

While IPC4D have many attractive features, building these coalitions is important for four additional reasons. First, the WTO has dominated current international intellectual property discussions, and group representation of less developed countries is particularly deficient in this international trading body. As Sonia Rolland (2007, 483) recently noted, "[a]lthough the organization operates on a one-country-one-vote basis and on a consensus mechanism ... developing countries still find themselves in a relatively marginalized position and experience difficulties in linking their development agenda to multilateral trade negotiations." Collective bargaining is therefore greatly needed.

Second, there is a rare and unprecedented opportunity for less developed countries to reshape the intellectual property debate. At recent WTO ministerial conferences in Doha, Cancún, and Hong Kong, less developed countries have built considerable momentum in pushing for reforms that would recalibrate the balance of the international trading system. In October 2007, WIPO also adopted a development agenda, including forty-five recommendations that range from technical assistance and capacity building to norm setting and public policy and from technology transfer to assessment, evaluation, and impact studies (WIPO 2007). In light of these developments, greater collaboration would help less developed countries take advantage of this momentum while protecting the gains they already have obtained in recent negotiations.

Third, and related to the second, the Doha Round will conclude soon, and development issues may not feature as prominently in the next round of WTO 
negotiations as in the current round. Indeed, without the urgency created by the September 11 tragedies, the fatalities caused by the 2001 anthrax attacks in the United States, and the United States' resulting general interest in working more closely with the less developed world, one has to wonder whether the Doha Round could have been negotiated as far as it has gotten (Amoore, Germain, and Wilkinson 2003, xiii). Thus, if less developed countries want to continue their success in future rounds of trade negotiations, they need to significantly increase their collective bargaining leverage.

Finally, the international intellectual property regime has recently expanded to cover issue areas that are traditionally covered by other international regime or fora, creating what I have termed the "international intellectual property regime complex" (Yu

$2007 \mathrm{c}, 13-21){ }^{3}$ As a result of its complexity and fragmentary nature, this conglomerate regime is likely to harm less developed countries more than it has harmed developed countries (Benvenisti and Downs 2007). The growing complexities have also upset the existing coalition dynamics between actors and institutions within the international trading system, thus threatening to reduce the gains made by less developed countries through past coalition-building initiatives (Yu 2007c, 17-18).

\section{COORDINATION STRATEGIES FOR DEVELOPING IPC4D}

To help develop IPC4D, this section discusses four different coordination strategies: (1) the initiation of South-South alliances; (2) the facilitation of North-South cooperation; (3) joint participation in the WTO dispute settlement process; and (4) the development of regional or pro-development fora. It also explains the need for, and benefits of, each strategy. Since these four strategies are not intended to be mutually exclusive, countries seeking to strengthen their bargaining position are encouraged to maximize the impact by using a combination of these strategies.

\section{South-South Alliances}

Since the failure of the fifth WTO Ministerial Conference in Cancún (Cancún Ministerial) in 2003, the United States has initiated a divide-and-conquer strategy that seeks to reward countries that are willing to work with the United States while undermining efforts by Brazil, India, and other G-20 members to establish a united negotiating front for less developed countries (Yu 2006a, 403). Although the United States had begun negotiating new bilateral and regional trade agreements before the failed ministerial conference, these agreements have been increasingly used as a means to isolate uncooperative less developed countries. As Robert Zoellick (2003), the former US trade representative, wrote in the Financial Times shortly after the Cancún Ministerial, the United States will attempt to separate the "can-do" countries from the "won't-do" countries and "will move towards free trade with [only] can-do countries."

This isolation strategy is not new. It was used by the United States to increase its bargaining leverage during the negotiations of the TRIPs Agreement. At that time, the United States used section 301 provisions to isolate major opposition countries, such as Argentina, Brazil, India, Japan, Mexico, South Korea, and Thailand (Yu 2004, 413). South Korea, for example, was threatened with sanctions for inadequate protection for 
computer programs, chemicals, and pharmaceuticals as well as in the areas of copyrights, patents, and trademarks (Watal 2001, 18). Likewise, the US trade representative included on the Section 301 Priority Watch List or Watch List half of the ten hardliner countries that refused to expand the mandate of the General Agreement on Tariffs and Trade to cover substantive intellectual property issues, namely Argentina, Brazil, Egypt, India, and Yugoslavia (Drahos 2002, 774).

If less developed countries are to counterbalance the United States' divide-andconquer strategy, lest more TRIPs-plus standards be developed at both the multilateral and regional levels, they need to initiate a combine-and-conquer strategy. Simply put, they need to build more coalitions within the less developed world. A recent successful example was the development of the G-20 during the Cancún Ministerial. Although its success was short-lived, the group was instrumental in preventing the WTO member states from reaching agreement on such issues as investment, competition policy, government procurement, and trade facilitation. Its success eventually led to the premature ending of the ministerial conference and the Bush administration's change of focus from multilateral negotiations to bilateral or regional agreements.

Today, there is a tendency to view bilateral or regional agreements with scepticism, partly as a result of their wide and controversial uses by the European Communities and the United States to ratchet up global intellectual property standards. However, it is important to distinguish these North-South agreements from the more favourable South-South agreements. Bilateral or regional agreements are not always destructive to the international intellectual property regime. Depending on their terms, South-South agreements may serve as an effective way to build coalitions within the less developed world. They may also promote multilateralism by fostering common positions among participating countries.

\section{North-South Cooperation}

Although the WTO and the international intellectual property regime remain heavily state-centred, the participation of non-state actors (such as multinational corporations and non-governmental organizations) and sub-state agents has grown considerably. During the Cancún Ministerial, "most high-profile [non-governmental organizations], such as Greenpeace, Oxfam, and Public Citizen, explicitly backed the developing countries' stand and heavily criticized developed countries, in particular the US and the EU, for a lack of consideration for their poorer trading partners" (Cho 2004, 235). While "[s]ome operated as think tanks in supporting the agenda of developing countries[, o]thers issued statements expressing political support for the demands of the G20" (Hurrell and Narlikar 2006, 424).

In addition, sub-state agents have become increasingly active. As Chris Alden $(2007,29)$ has noted with respect to China's government and business ties in Africa, Chinese provincial and municipal authorities have undertaken major initiatives to establish formal and informal ties in South Africa, the Democratic Republic of Congo, Namibia, Angola, and Nigeria. In recent years, there has also been an interesting emergence of non-national systems, such as the adoption of the Uniform Domain Name 
Dispute Resolution Policy (UDRP) in October 1999 by the Internet Corporation for Assigned Names and Numbers (ICANN), a private not-for-profit corporation in California (Yu 2007a, 88-91).

Thus, instead of focusing on state-to-state relationships, less developed countries need to better understand the importance and challenges for working with nongovernmental organizations and sub-state agents and within non-national systems. They also "need to work consistently with US and European political allies to alter the US and European domestic political contexts" (Shaffer 2004, 479). In doing so, these allies will be able to obtain support within the domestic deliberative processes in developed countries that is similar to the support they have already received within their own countries or in the less developed world. As Gregory Shaffer (ibid., 480) elaborates:

Domestic and international non-governmental advocates, such as ACT UP, Doctors Without Borders, and Oxfam, ... raise fundamental moral issues to hold US and EC political leaders accountable. They also harness the public's self-interest over the cost of prescription drugs and public officials' struggles to finance health care commitments within the United States and Europe themselves.

Even if these countries are unable to obtain their desirable policy outcomes through the political processes in the developed world, their foreign allies may be able to significantly reduce the political pressure developed countries will exert upon their less developed counterparts. As Shaffer (ibid., 479-80) continues:

If developing countries cannot neutralize the clout of large pharmaceutical firms in the formation of US and European positions, then developing countries will face the full brunt of US and European coercion in the negotiation and enforcement of pharmaceutical patent rights. In a world of asymmetric power, developing countries enhance the prospects of their success if other US and European constituencies offset the pharmaceutical industry's pressure on US and European trade authorities to aggressively advance industry interests.

Despite the importance of cultivating allies in other countries, this point is sometimes lost on less developed countries, whose "domestic lobbies have played a much smaller role in determining foreign economic policy than in the developed democracies" (Narlikar 2003, 4).

To date, there has been significant collaboration between policy makers in less developed countries and non-governmental organizations in both developed and less developed countries. Intergovernmental and non-governmental organizations that have been active in the public health area include ACT UP!, Health Action International, Health GAP, the International Centre for Trade and Sustainable Development (ICTSD), Knowledge Ecology International (formerly the Consumer Project on Technology), Médecins Sans Frontières (MSF), Oxfam, the South Centre, the Third World Network, the Trade Law Centre for Southern Africa (tralac), and the Treatment Action Campaign, among others. As these North-South alliances are built and strengthened, they will be able to push for policies that will support greater access to essential medicines in less developed countries. 


\section{BUILDING IPC4D TO PROMOTE ACCESS TO ESSENTIAL MEDICINES}

Academics and the media in the North can also play important roles. For example, academics and their institutions have helped identify policy choices and negotiating strategies while developing technical capacity in less developed countries. Likewise, less developed countries can increase their leverage and negotiating outcomes if they are able to "capture ... the attention of the mass media in industrial countries and persuade ... the media to reframe the issue using a reference point more favorable to the coalition's position" (Odell and Sell 2006, 87). As John Braithwaite and Peter Drahos $(2000,576)$ note, "[h] ad TRIPS been framed as a public health issue, the anxiety of mass publics in the US and other Western states might have become a factor in destabilizing the consensus that US business elites had built around TRIPS."

In addition, commentators have underscored the need to design and stimulate alliances between generic manufacturers in the developed and less developed worlds. With caution, cooperation between brand name and generic manufacturers can also be beneficial, although commentators are generally wary of such cooperation. If developed properly, these two sets of alliances "can provide efficiencies, foster dynamic competition, enhance their competitive ability and benefit consumers" (Rosenberg 2006, 76). To obtain maximum benefits, these alliances can be set up not only within the less developed world, but also between the developed and less developed worlds-perhaps with the assistance of intergovernmental and non-governmental organizations. It may also be helpful for public authorities in less developed countries to coordinate strategies with the private generic pharmaceutical sector (Shaffer 2004, 481).

Finally, North-South cooperation can go beyond a specific field. For instance, it may be useful to develop cross-discipline cooperation linkages between health and medical experts in the North and intellectual property offices in the South. As commentators have noted, the participation of health officials and ministries in trade negotiations is scant and inadequate (Musungu, Villanueva, and Blasetti 2004, 77).

Most recently, Professor Drahos (2008) advocated coordination between patent offices and health and medical experts in making assessment of an invention's contribution to innovation and health welfare. Drawing on experience of ANVISA, the Brazilian National Health Surveillance Agency, he explained that these experts are likely to be in a much better position than patent examiners to make such an assessment. While there is no doubt that the Brazilian model and greater cooperation between patent offices and health experts will benefit many less developed countries, such a model is not limited to the country or the region. Greater cooperation between intellectual property offices in the South and health and medical experts and related non-governmental organizations in the North is likely to be equally, or if not more, fruitful.

\section{The WTO Dispute Settlement Process}

One of the major features of the WTO is its mandatory dispute settlement process. Although the United States and the European Communities had used the process predominantly in the first few years of the WTO's existence, especially when the disputes involved the TRIPs Agreement, less developed countries have begun to use the process more actively in recent years (Davey 2005, 17 and 24). While Brazil and India initially 
used the process primarily against less powerful WTO member states, such as Argentina, Turkey, Mexico, Peru, and Poland, they have started to use the process more aggressively against powerful WTO member states, such as the European Communities and the United States.

Today, globalization and international trade have deeply affected domestic policies, and an active participation in the WTO dispute settlement process is of paramount importance to WTO member states. By participating in it, countries can help develop WTO jurisprudence in a way that can shape the ongoing negotiations in the areas of international trade, intellectual property, and even public health. Gregory Shaffer (2004, 470) describes such participation as negotiation "in the shadow of" the WTO dispute settlement process. As he explains:

Participation in WTO judicial processes is arguably more important than is participation in analogous judicial processes for shaping law in national systems. The difficulty of amending or interpreting WTO law through the WTO political process enhances the impact of WTO jurisprudence. WTO law requires consensus to modify, resulting in a rigid legislative system, with rule modifications occurring through infrequent negotiating rounds. Because of the complex bargaining process, rules often are drafted in a vague manner, thereby delegating de facto power to the WTO dispute settlement system to effectively make WTO law through interpretation.

As a result of the increased importance of WTO jurisprudence and the rigidity of the WTO political process, those governments that are able to participate most actively in the WTO dispute settlement system are best-positioned to effectively shape the law's interpretation and application over time.

Shaffer's approach makes a lot of sense. After all, there is no indication that the WTO dispute settlement panels are biased toward stronger protection of intellectual property rights. In the decisions issued thus far, the panellists have focused narrowly on the language of the TRIPs Agreement, taking into consideration the recognized international rules of interpretation, the context of the TRIPs negotiations, and the past and subsequent developments of relevant treaties. In Canada-Patent Protection of Pharmaceutical Products (WTO 2000a, para. 7.26), the panel even referred favourably to the limitations and public interest safeguards contained in the TRIPs Agreement. As the panel declared, "[b]oth the goals and the limitations stated in Articles 7 and 8.1 must obviously be borne in mind when [examining the words of the limiting conditions in article 30] as well as those of other provisions of the TRIPS Agreement which indicate its object and purposes."

Moreover, as I have noted elsewhere in the context of the United States' ongoing WTO dispute with China over the lack of intellectual property enforcement, the European Communities and the United States did not win all of the disputes "litigated" before the Dispute Settlement Body (Yu 2006b, 939-40). In June 2000, for example, the United States lost its dispute with the European Communities over section 110(5) of the US Copyright Act, which enables restaurants and small establishments to play copyrighted music without compensating copyright holders (WTO 2000b). In a subsequent ruling, section 211(a)(2) of the US Omnibus Appropriations Act of 1998, which prohibits the registration or renewal of trademarks previously abandoned by trademark holders whose 
business and assets have been confiscated under Cuban law, was found to be inconsistent with the TRIPs Agreement (WTO 2002).

In addition, the WTO panel curtailed the ability of the US administration to pursue retaliatory actions before exhausting all remedies permissible under the WTO rules, even though it nominally upheld sections 301-310 of the Trade Act of 1974 (WTO 1999). Most recently, the Caribbean islands of Antigua and Barbuda successfully challenged US laws on Internet and telephone gambling in United States-Measures Affecting the Cross-Border Supply of Gambling and Betting Services (WTO 2004). An arbitration panel subsequently determined that "the annual level of nullification or impairment of benefits accruing to Antigua is US\$21 million” (WTO 2007).

While many of the United States' losses before the WTO Dispute Settlement Body have come at the hand of the European Communities, the WTO dispute settlement process is not only reserved for use by powerful WTO member states. The last dispute has shown that, in the WTO process, even two tiny Caribbean islands can prevail over a trading giant like the United States. One can imagine how effective the use of this process can be when less developed countries team up with others as co-complainants or third parties. On the one hand, such a collective effort can pull together scarce economic and legal resources to defend laws that seek to exploit the flexibilities provided by the TRIPs Agreement and that are explicitly affirmed by paragraph 5 of the Doha Declaration. On the other hand, less developed countries can use these resources to design effective strategies to challenge non-TRIPs-compliant legislation in developed countries.

Compared to the uncoordinated arrangement where each country has to file a separate complaint, or join the complainant as a third party, the collaborative strategy has at least five benefits. First, countries will be able to significantly reduce the costs of WTO litigation, thus lowering the threshold for determining whether it would be worthwhile to file a WTO complaint. Shaffer's $(2004,473)$ analysis has shown how it may not be worthwhile for a small or poor country to file a WTO complaint even when there is a high economic stake. Based on 2004 figures, he found that "an average WTO claim cost[] in the range of US $\$ 300,000-400,000$ in attorneys' fees.” Although a potential loss of US $\$ 200,000$ in trade may be highly important to the economy of a small, poor country, such a loss does not always justify taking the case to the WTO Dispute Settlement Body or defending it there. Instead, these countries often give up their valid claims (ibid., 472). If they are sued, they often settle the claims either by abandoning legal or policy experiments that are permissible under the WTO agreements or by transplanting laws from abroad against their wishes and to their detriment.

Such an outcome is particularly problematic from the standpoint of the TRIPs negotiations. One of the primary reasons why less developed countries reluctantly agreed to increase intellectual property protection is the ability to use the WTO dispute settlement process as a bulwark against developed countries' coercive, and often unilateral, tactics. As some less developed countries claimed at the time of the negotiations, it would be pointless for them to join the WTO if the United States were able to continue imposing unilateral sanctions despite their membership (Yu 2006a, 372). Unfortunately, the high start-up costs required by the WTO dispute settlement process 
have made it very difficult for less developed countries to benefit from the hard-earned bargains they won through the WTO negotiations.

More problematically, the lack of participation by some less developed countries in the WTO dispute settlement process can hurt the protection of other less developed countries. As Shaffer $(2004,465)$ reminds us, "[w]ho participates in the institutional process affects which arguments will be presented, which, in turn, affects how the competing concerns over patent protection, public health, and market competition will be weighed." Thus, if the WTO rules are to be shaped to advance the interests of the less developed world, greater participation by less developed countries in the WTO dispute settlement process is needed.

Less developed countries can also benefit from the additional expertise and resources provided by other less developed countries. Instead of spending a substantial amount of money on outside counsel or spending even more in developing local expertise, less developed countries can take advantage of cost-sharing arrangements and devote more resources to improving the living standards of their nationals (ibid., 475). If these countries team up with countries such as Brazil, China, or India, they can benefit from even more sophisticated expertise. Since the latter are active litigants in the WTO dispute settlement process, over the years they have developed considerable expertise that can be shared with other less developed countries.

Moreover, as repeat players in WTO litigation, less developed countries will benefit from the economies of scale in deploying legal resources (ibid., 474). They are also more likely to possess the mindset to plan legal strategies that will help them advance the interests of the less developed world and strengthen their overall legal positions, rather than strategies that seek to win only one case at a time (ibid., 470). In doing so, these countries can use the WTO dispute settlement process effectively to shape both the judicial interpretation and the future negotiation of the TRIPs Agreement in a pro-development manner. They may even be able to regain the momentum that less developed countries lost during the negotiations of the TRIPs Agreement due to their limited understanding of intellectual property rights and weak bargaining power. Thus far, the European Communities and the United States have been able to advance their commercial interests through the WTO dispute settlement process because they are the predominant users of this process (ibid., 470). If less developed countries are to curtail the ability by developed countries to advance these interests, they therefore need to make greater strategic use of the WTO dispute settlement process.

A further benefit of this collective approach is that less developed countries do not need to worry as much about the backlash they might encounter should they individually file a WTO complaint against the European Communities or the United States. As William Davey $(1987,71)$ has noted, when countries do not face each other often as adversaries in the WTO process, "initiation of a complaint would be something of a slap in the face. The ignominy of a loss would also loom larger." By taking collective action, many otherwise infrequent players in the WTO dispute settlement process will become more frequent players. As they become involved in more complaints against the European Communities or the United States, and as each of these parties has 
its share of wins and losses, the impact of a WTO dispute on diplomatic relations will be greatly reduced (Yu 2006b, 945).

Finally, less developed countries may not "have the diplomatic or economic muscle to ensure that the decision is implemented" even if they win their case (Davey 1987, 90). Indeed, as Davey (ibid., 102) points out, there is a good chance that "even massive retaliation by a small country would be unnoticed by a larger one." Thus, by uniting together, less developed countries may be able to have more leverage at the enforcement level by increasing the economic impact of trade countermeasures permitted by the WTO dispute settlement panel.

\section{Regional or Pro-Development Fora}

Regional or pro-development fora are particularly effective means for coordinating efforts by less developed countries in the areas of public health, intellectual property, and international trade. These fora will provide the much-needed focal points for countries to share experience, knowledge, and best practices and to coordinate negotiation and litigation strategies (Musungu, Villanueva, and Blasetti 2004, xiv-xv; Narlikar 2003, 206; Shaffer 2004, 478). Through these fora, less developed countries can "(i) raise political awareness of certain members ... (ii) help define the agenda, prior to the actual negotiations . . . and (iii) achieve particular regulatory outcomes on a particular issue or economic sector or sub-sector ... and defend interests in dispute settlement" (Rolland 2007, 499).

In addition, these fora allow countries to reframe issues "in a way that eases impasses" (Odell 2006, 16), thereby providing a mechanism to balance interests internal to the group. In doing so, conflicts or negotiation deadlocks can be resolved before the negotiations are enlarged to include selected developed countries or the entire developed world (Rolland 2007, 501). These fora also facilitate "a pooling of organisational resources, and enable countries with ill-defined interests to avail themselves of the research efforts of allies and a possible country-wise division of research and labour across issue areas" (Narlikar 2003, 14).

Through these fora, the interests of the participating countries would be better and more symmetrically represented (Rolland 2007, 512). The fora would also "help build capacity for the group's members as they would gain leverage through access to a more central and streamlined channel of information (through the group representation) and, in turn, be able to better formulate their own policy positions" (ibid., 512). In addition, regional or pro-development fora could help improve the human capital and WTO knowhow of less developed countries by "better coordinat[ing] training of developing country officials and non-governmental representatives" (Shaffer 2004, 478). These capacitybuilding functions are especially important, considering the fact that some less developed countries have given up their participation in international fora due to a lack of financial resources or political circumstances.

As commentators have pointed out, many less developed countries "lack the resources .... to send delegates to these fora and thus have resorted to using 
nongovernmental organizations ... to represent their interests" (McGinnis and Movsesian 2000, 557 n. 256). In one instance, the Foundation for International Environmental Law and Development, a London-based environmental NGO, negotiated a deal to represent Sierra Leone before the WTO Committee on Trade and Environment (Shaffer 2001, 62-63). Even if countries are willing to send delegates, they may have become formally inactive due to their failure to pay dues for a certain period of time. Within the WTO, for example, their inactive status would prevent them from chairing any bodies (Narlikar 2003, 15). Many delegations are also affected by their limited institutional capacity, delegation size, geopolitical capital, and overall expertise (Rolland 2007, 529).

Coordination at the regional level and among less developed countries becomes even more important in light of the proliferation of bilateral and regional trade agreements initiated by the European Communities and the United States. Since these agreements tend to transplant laws based on developed-country models, they are notorious for ignoring local needs, national interests, technological capabilities, institutional capacities, and public health conditions of less developed countries. Even worse, these agreements sometimes call for a higher level of protection than what is currently offered in the developed world (Correa 2004, 93; Yu 2006c, 41). If the European Communities or the United States does not consider it beneficial to have higher protection, one has to wonder why protection needs to be strengthened in countries that have even more limited resources and that do not possess adequate safeguards and correction mechanisms.

If these demands for higher protection are not disturbing enough, less developed countries may be "induced" into signing conflicting agreements with both the European Communities and the United States (Yu 2006a, 407). While these two trading powers are interested in having strong global intellectual property standards, there remain a large number of intellectual property conflicts between the two. In the copyright context, for example, they take different positions on "the protection of moral rights, fair use, the first sale doctrine, the work-made-for-hire arrangement, and protection against private copying in the digital environment" ( $\mathrm{Yu}$ 2002, 625-26). They also approach the patent filing process differently and greatly disagree on how to protect geographical indications (WTO 2005). Indeed, had the United States refused to include geographical indications in the then-proposed TRIPs Agreement, the European Communities' initial ambivalent position toward the creation of the new agreement might not have changed (Watal 2001, 23).

In view of these differences, conflicts may arise when less developed countries sign the trade agreements supplied by both the European Communities and the United States without appropriate review and modification. To be certain, it is not the fault of these trading powers that policy makers in less developed countries are unable to review or modify the agreement. Oftentimes, it is the result of a lack of resources, expertise, leadership, negotiation sophistication, bargaining power, or some or all of the above. Many policy makers in less developed countries are also blinded by the benefits that their countries may receive in other trade areas under a package deal—or, worse, they are just too eager to appease, or develop "friendship" with, the trading powers. Nevertheless, it is 
still highly lamentable that these countries would enter into conflicting agreements that could be avoided with greater caution, coordination, and information. It is bad enough to be forced to sign a bilateral agreement that does not meet local conditions. It is even worse to be put into a position where one has to juggle two conflicting agreements that do not meet local conditions and are impossible to honour.

Fortunately for less developed countries, regional or pro-development fora may provide the much-needed institutional response to the growing use of bilateral and regional trade agreements to push for stronger intellectual property standards and to further reduce the policy space needed for the development of intellectual property, trade, and public health policies. While the constantly short-staffed Advisory Centre on WTO Law provides legal advice and support in WTO matters and trains government officials in WTO law, they do not provide assistance in coordinating political, judicial, and forumshifting strategies in an increasingly complex international intellectual property lawmaking environment (Shaffer 2004, 478). They also provide very limited assistance in developing negotiating strategies concerning the bilateral or regional trade agreements initiated by the European Communities and the United States.

By bringing less developed countries together, these fora would allow policy makers in those countries to share their latest experience and lessons concerning these agreements. In doing so, the participating countries would have more information to evaluate the benefits and drawbacks of the potential treaties. They would also be able to anticipate problems and potential side effects created by these treaties. They might even be able to better design prophylactic or correction measures that would become handy should the treaties prove to be unsuitable for their countries.

Finally, as Sonia Rolland (2007, 505) points out, "the ability or inability of developing countries to form and sustain effective coalitions in the WTO depends not only on the coalitions' inherent characteristics and the political environment . . . but also on the institutional and legal framework in which they operate." Except for supranational entities such as the European Communities, special classifications such as least developed countries, or recognized regional trade agreements, the WTO offers very limited support for formal representation by groups in policy deliberation. Thus, if less developed countries can use these regional or pro-development fora to develop strategies to push for greater legal or structural changes within international organizations that will make group representation easier to obtain and the institution more coalition-friendly, they are more likely to be able to increase their bargaining leverage and to develop a stronger voice for the less developed world. After all, "the ability to sustain developing country coalitions depends in part on the WTO's legal structure .... [M] embers whose interests might be more effectively served if they are promoted by a group strategy could [also] benefit from a legal framework that better supports developing country coalitions or groupings" (ibid., 485).

\section{CHALLENGES TO BUILDING IPC4D}

Although collective action can play an important role in the international intellectual property regime and the use of the coordination strategies described in this 
chapter can help less developed countries strengthen their collective bargaining position, there are still many challenges. This section highlights some of these challenges.

Historically, less developed countries have had only limited success in using coalition-building efforts to increase their bargaining leverage (Abbott 2003, 42). Their lack of success was perhaps caused by the fact that these coalitions were usually too ambitious. They were set up to include a broad mandate, diverse membership, complex issues, and incompatible interests. As Amrita Narlikar (2003, 122-23) has shown, issuebased coalitions work best for small and very specialized economies with common profiles and interests, such as those "small island economies with similar geographic/strategic endowments, concentrated interests in tourism exports, and travel imports." These coalitions, however, do not work well for larger, more diverse, and often internally conflicting economies (ibid., 176). They also do not work well for a large bloc of less developed countries that have various strengths, sizes, and interests and that are only linked together in an ad hoc fashion (Rolland 2007, 510).

The lack of success by less developed countries to build or maintain coalitions can be further attributed to their "high ... . dependen[ce] on the developed countries as the source of capital, whether it is provided through the IMF [International Monetary Fund] or World Bank, or through investment bankers and securities exchanges" (Abbott 2003, 42). This lack of financial independence is further aggravated by a lack of stability in the economies of less developed countries - for example, in India during the negotiations of the TRIPs Agreement and in South America during the negotiation of the draft International Code of Conduct on the Transfer of Technology (Yu 2008b).

Another challenge for less developed countries concerns how to set up a coalition in a way that would prevent the more powerful members from dominating their much weaker and more dependent partners. Since countries with more human capital, technical knowledge, and legal expertise may abuse their leadership roles at the expense of others, it is important to build safeguards into the coalitions to protect the weaker members and to allow them to retain their autonomy and identity. If IPC4D are to be successfully built and maintained, it is also important to develop trust among the participating members so that they can work together closely without worrying about potential exploitation.

These safeguards are particularly important in light of the complex economic interests of the larger developing countries, such as Brazil, China, and India, all of which have grown significantly faster than their poorer neighbours. In many areas of international trade, these middle-income developing countries already "have gained relatively more than their poorer counterparts from the multilateral trade process [and] have increasingly found themselves adopting positions divergent from those of [their poorer counterparts] on the question of preferential access to rich country markets" (Rolland 2007, 536). If history repeats itself, as in the cases of the United States, Germany, Japan, and South Korea, some of these countries eventually will want stronger intellectual property protection once they become economically developed. They may also benefit from the continued lack of manufacturing capacity in other less developed countries. 


\section{BUILDING IPC4D TO PROMOTE ACCESS TO ESSENTIAL MEDICINES}

To complicated matters, the economic interests of pharmaceutical manufacturers have grown rapidly in middle-income developing countries, and these countries are eager to exploit their comparative advantages by serving as regional research-and-development or supply centres. One may still remember the remark by PhRMA representative Tom Bombelles where he suggested "South Africa was a pawn used by India and Argentina to undermine TRIPS" (Halbert 2002, 267). Although this remark sought to "shift the focus [unfairly] away from the enormous health crisis in Africa" (ibid., 267-68), it signalled a problem that would arise if the debate became whether the developed or middle-income developing countries would supply medication to other less developed countries.

Moreover, the dynamic development of the pharmaceutical sector has made it difficult for countries to assess their self-interests and for coalitions to be maintained. As Dwijen Rangnekar (2007, 379-80) points out:

[I]n 1999 [there emerged] a new configuration of pharmaceutical firms, the Indian Pharmaceutical Alliance (the Alliance), consisting of firms like Cipla, Dr Reddy's Laboratories, Lupin Laboratories and Ranbaxy that collectively account for $30 \%$ of domestic production and $33 \%$ of Indian exports. The Alliance is composed of pharmaceutical firms with mixed interests and areas of expertise: "[the Alliance] ... is perhaps a little schizophrenic about where its members' interests lie. On the one hand many of them, such as Ranbaxy, wish to develop as research based companies and see the value of strong patent protection to achieve that. On the other hand, the overwhelming majority of their revenues remain derived from generic production, and accordingly they share many of the concerns of [the Indian Drug Manufacturers' Association, a key domestic group of generic manufacturers]."

As the economy of these countries matures, the structure of the pharmaceutical sector may change even further. In 2007, for example, "Merck partnered with Advinus Therapeutics, an Indian company, to develop drugs for metabolic disorders, with Merck retaining the right to advance research into late-stage clinical trials. GlaxoSmithKline and Ranbaxy have also teamed up" (Nath 2008, 102). Such partnerships between brand name and generic manufacturers have made it particularly difficult for countries to assess their economic self-interests.

Finally, there are "IP-irrelevant" factors-factors that are largely unaffected by intellectual property protection (Yu 2007b, 852-53) - that would make it difficult for countries to co-operate with each other, such as xenophobia, nationalism, racism, mistrust, and resentment. No matter how much more globalized and interdependent the world has become, some countries will always remain reluctant to participate in these coalitions, because of historical conflicts, border disputes, economic rivalries, cultural differences, or spill-over issues from other areas.

The existence of all of these challenges, however, does not doom the IPC4D project. Rather, it demonstrates how coalition building is always a work in progress that requires care, vision, and continuous attention between and among the various parties. It also suggests the importance of using regional approaches to alleviate the impact of some of these factors. If the interests of the weaker coalition members are to be protected, a clear and detailed coalition agreement and a carefully designed benefit-sharing 
arrangement need to be put in place when the coalition is set up. It is also important for the weaker members to obtain a better understanding of how they can take advantage of the coalitions when the interests of the members are still close to each other.

\section{CONCLUSION}

There are many benefits to building IPC4D. There are some challenges, however. If countries are to work together to develop successful coalitions, they need to clearly articulate their goals, understand each other better, and work out mutually beneficial arrangements. In doing so, the development of IPC4D is not a mere hope but a realistic goal. The resulting coalitions will not only be able to reduce the ongoing push by the European Communities and the United States to ratchet up global intellectual property standards, but they will also help enlarge the policy space needed by less developed countries for the development of their intellectual property, trade, and public health policies. With better coordination and greater leverage, these countries may even be able to establish, shape, and enlarge a pro-development negotiating agenda that would restore the balance of the international intellectual property system while promoting access to essential medicines in the less developed world.

\section{NOTES}

1. Although the initial deadline for ratification was 1 December 2007, the deadline has been recently extended for another two years (New 2007). As of this writing, slightly over a quarter of the 153 WTO member states, including the United States, India, Japan, China, and most recently members of the European Communities, have ratified the proposed amendment (WTO 2008).

2. The TRIPs Agreement distinguishes between developing and least developed countries. This chapter uses "less developed countries" to denote both developing and least developed countries. When referring to the TRIPs Agreement, however, the chapter returns to the terms "developing countries" and "least developed countries."

3. The term "regime complex" originated from Kal Raustiala and David Victor (2004). David Leebron $(2002,18)$ has also advanced the concept of "conglomerate regime" to describe this new development.

\section{REFERENCES}

Abbott, Frederick. 2003. "The Future of IPRs in the Multilateral Trading System." In Trading in Knowledge: Development Perspectives on TRIPS, Trade and Sustainability, ed. Christophe Bellmann, Graham Dutfield, and Ricardo Melendez-Ortiz, 36-44. London: Earthscan Publications.

Abbott, Frederick M., and Jerome H. Reichman. 2003. “The Doha Round's Public Health Legacy: Strategies for the Production and Diffusion of Patented Medicines under the Amended TRIPS Provisions." Journal of International Economic Law 10: 921-87.

Alden, Chris. 2007. China in Africa. London: Zed Books. 
Amoore, Louise, Randall Germain, and Rorden Wilkinson. 2003. "Series Preface." In International Trade and Developing Countries: Bargaining Coalitions in the GATT and WTO, ed. Amrita Narlikar, xiii-xiv. London: Routledge.

Benvenisti, Eyal, and George W. Downs. 2007. "The Empire's New Clothes: Political Economy and the Fragmentation of International Law." Stanford Law Review 60: 595-631.

Bird, Robert, and Daniel R. Cahoy. 2008. "The Impact of Compulsory Licensing on Foreign Direct Investment: A Collective Bargaining Approach." American Business Law Journal 45: 283-330.

Braithwaite, John, and Peter Drahos. 2000. Global Business Regulation. Cambridge: Cambridge University Press.

Cho, Sungjoon. 2004. "A Bridge Too Far: The Fall of the Fifth WTO Ministerial Conference in Cancún and the Future of Trade Constitution." Journal of International Economic Law 7: 219-44.

Coleman, William D., and Geoffrey R.D. Underhill. 1998. "Introduction: Domestic Politics, Regional Economic Co-operation, and Global Economic Integration." In Regionalism and Global Economic Integration: Europe, Asia and the Americas, ed. William D. Coleman and Geoffrey R.D. Underhill, 1-16. London: Routledge.

Correa, Carlos M. 2004. "Bilateralism in Intellectual Property: Defeating the WTO System for Access to Medicines." Case Western Reserve Journal of International Law 36: 79-94.

Davey, William J. 1987. "Dispute Settlement in GATT." Fordham International Law Journal 11: 51-109.

-. 2005. "The WTO Dispute Settlement System: The First Ten Years." Journal of International Economic Law 8: 17-50.

Drahos, Peter. 2002. "Developing Countries and International Intellectual Property Standard-Setting." Journal of World Intellectual Property 5: 765-89.

-. 2008. "Trust Me': Patent Offices in Developing Countries." American Journal of Law and Medicine 34: 151-74.

Halbert, Debora. 2002. "Moralized Discourses: South Africa's Intellectual Property Fight for Access to AIDS Drugs.” Seattle Journal for Social Justice 1: 257-88.

Hurrell, Andrew, and Amrita Narlikar. 2006. "A New Politics of Confrontation? Brazil and India in Multilateral Trade Negotiations." Global Society 20: 415-33.

Leebron, David W. 2002. "Linkages." American Journal of International Law 96: 5-27.

McGinnis, John O., and Mark L. Movsesian. 2000. "The World Trade Constitution." Harvard Law Review 114: 511-605.

Musungu, Sisule F., Susan Villanueva, and Roxana Blasetti. 2004. Utilizing TRIPS Flexibilities for Public Health Protection through South-South Regional Frameworks. Geneva: South Centre.

Narlikar, Amrita. 2003. International Trade and Developing Countries: Bargaining Coalitions in the GATT and WTO. London: Routledge.

Nath, Kamal. 2008. India's Century. New York: McGraw-Hill.

New, William. 2007. "TRIPS Council Extends Health Amendment; Targets Poor Nations' Needs." Intellectual Property Watch, 23 October, http://www.ipwatch.org/weblog/index.php?p=798. 
Odell, John S. 2006. "Introduction." In Negotiating Trade: Developing Countries in the WTO and NAFTA, ed. John S. Odell, 1-38. Cambridge: Cambridge University Press.

-, and Susan K. Sell. 2006. "Reframing the Issue: The WTO Coalition on Intellectual Property and Public Health, 2001." In Negotiating Trade: Developing Countries in the WTO and NAFTA, ed. John S. Odell, 85-114. Cambridge: Cambridge University Press.

Rangnekar, Dwijen. 2007. "Context and Ambiguity in the Making of Law: A Comment on Amending India's Patent Act." Journal of World Intellectual Property 10: 365-87.

Raustiala, Kal, and David G. Victor. 2004. "The Regime Complex for Plant Genetic Resources." International Organization 58: 277-309.

Rolland, Sonia E. 2007. "Developing Country Coalitions at the WTO: In Search of Legal Support." Harvard International Law Journal 48: 483-551.

Rosenberg, Barbara. 2006. "Market Concentration of the Transnational Pharmaceutical Industry and the Generic Industries: Trends on Mergers, Acquisitions and Other Transactions." In Negotiating Health: Intellectual Property and Access to Medicines, ed. Pedro Roffe, Geoff Tansey, and David Vivas-Eugui, 65-78. London: Earthscan Publications.

Shaffer, Gregory C. 2001. "The World Trade Organization under Challenge: Democracy and the Law and Politics of the WTO's Treatment of Trade and Environment Matters." Harvard Environmental Law Review 25: 1-93.

-. 2004. "Recognizing Public Goods in WTO Dispute Settlement: Who Participates? Who Decides? The Case of TRIPS and Pharmaceutical Patent Protection." Journal of International Economic Law 7: 459-82.

Watal, Jayashree. 2001. Intellectual Property Rights in the WTO and Developing Countries. The Hague: Kluwer Law International.

World Intellectual Property Organization (WIPO). 2007. Member States Adopt a Development Agenda for WIPO. 1 October, http://www.wipo.int/pressroom/en/articles/2007/article_0071.html.

World Trade Organization. 1999. United States-Sections 301-310 of the Trade Act of 1974. WTO Panel Report. Doc. WT/DS152/R.

-. 2000a. Canada-Patent Protection of Pharmaceutical Products. World Trade Organization Panel Report. Doc. WT/DS114/R.

-. 2000b. United States-Section 110(5) of the U.S. Copyright Act. WTO Panel Report. Doc. WT/DS/160/R.

-. 2002. United States-Section 211 Omnibus Appropriations Act of 1998. WTO Appellate Body Report. Doc. WT/DS176/AB/R.

-. 2004. United States-Measures Affecting the Cross-Border Supply of Gambling and Betting Services. WTO Panel Report. Doc. WT/DS285/R.

-.2005. European Communities-Protection of Trademarks and Geographical Indications for Agricultural Products and Foodstuffs. WTO Panel Report. Doc. WT/DS174/R.

-. 2007. United States-Measures Affecting the Cross-Border Supply of Gambling and Betting Services. WTO Arbitration Panel Report. Doc. WT/DS285/ARB. 
-.2008. Countries Accepting Amendment of the TRIPS Agreement. 23 May, http://www.wto.org/english/tratop_e/trips_e/amendment_e.htm.

Yu, Peter K. 2002. "Toward a Nonzero-sum Approach to Resolving Global Intellectual Property Disputes: What We Can Learn from Mediators, Business Strategists, and International Relations Theorists." University of Cincinnati Law Review 70: 569650.

-. 2004. "Currents and Crosscurrents in the International Intellectual Property Regime." Loyola of Los Angeles Law Review 38: 323-443.

-. 2006a. "TRIPS and Its Discontents." Marquette Intellectual Property Law Review 10: 369-410.

-. 2006b. "From Pirates to Partners (Episode II): Protecting Intellectual Property in PostWTO China." American University Law Review 55: 901-1000.

-. 2006c. "Anti-circumvention and Anti-anticircumvention." Denver University Law Review 84: 13-77.

-. 2007a. "Five Disharmonizing Trends in the International Intellectual Property Regime." In Intellectual Property and Information Wealth: Issues and Practices in the Digital Age, ed. Peter K. Yu, volume 4, 73-111. Westport: Praeger Publishers.

-. 2007b. "The International Enclosure Movement." Indiana Law Journal 82: 827-907.

-. 2007c. "International Enclosure, the Regime Complex, and Intellectual Property Schizophrenia." Michigan State Law Review 2007: 1-33.

-. 2008a. "Access to Medicines, BRICS Alliances, and Collective Action." American Journal of Law and Medicine 34: 345-94.

-. 2008b. "A Tale of Two Development Agendas." Ohio Northern University Law Review 35 [forthcoming].

Zoellick, Robert B. 2003. "America Will Not Wait for the Won't-Do Countries." Financial Times, 22 September, 23. 